\title{
African American Wounds: Broken Memories and the Traumatic Outcome of Racist Stereotypes in Bernice L. McFadden's Gathering of Waters
}

\author{
Vicent Cucarella-Ramon
}

Department of English and German Philology, University of Valencia, Spain

Copyright (C) 2015 by authors, all rights reserved. Authors agree that this article remains permanently open access under the terms of the Creative Commons Attribution License 4.0 International License

\begin{abstract}
The haltingly dark past of the United States has proved to be utterly decisive in the formation of an unalloyed epistemology for African Americans. The blatant racism relegated them to the margins of the young nation ever since its foundation. Thus, trauma and sorrow have evolved into challenging concepts which overlap taking into account the transnational and transcultural memory of a considerable part of the African American population. Drawing on the concept of trauma as proposed by critics such as Cathy Caruth or Dominick LaCapra, this article analyzes Bernice L. McFadden's novel Gathering of Waters, published in 2013, as a literary account of the aftermaths that result from the traumatic experiences that African American population have historically had to put up with. Namely, I contend that the racist stereotypes of the lustful Jezebel and the myth of the 'buck' as a violent and virile black man have a direct impact in the tragic destiny that falls upon the main characters Tass Hilson and Emmett Till respectively. I submit that Tass' meandering into madness and the eventual assassination of Emmett Till are blunt results of the interiorization of the racist stereotypes that white America created to justify the violence impinged on African Americans. The novel totters beautifully and tragically on the precipice of the traumatic past to explain the racial nightmares of contemporary North America and nurtures readers to digest the broken soul of black Americans.
\end{abstract}

Keywords Stereotypes, Racism, Memory

Oh, what sorrow?

Pity, pain,

That tears and blood

Should mix like rain

In Mississippi!

And terror, fetid hot,
Yet clammy cold

Remain.

Langston Hughes, Mississippi (1955).

"I write to breath life back into memory".

Bernice L. Mc Fadden.

\section{Introduction}

The consolidation of the "memory boom", as Andreas Huyssen (2000) coined it, in the fields of cultural and literary studies represents not a turning away from the tumultuous concerns of the present but a means to grapple with how the consequences of the past continue to inform and alter the present thus attesting a national continuum between history and memory.

In this light, he terrible and haltingly dark past of the North American nation has proved to be utterly decisive in the formation of an unalloyed epistemology for African Americans. The blatant racism, exclusion, and all the subsequent vexations endured relegate them to the margins of the young nation ever since its foundational grounds. Slavery, up until the $19^{\text {th }}$ century, and Segregation, which was legal until the mid-twentieth century, became inextricable parts of the African Americans' memory and defined their attempt to succeed in American society. Accordingly, for black Americans memory and culture merged to foster a new (African) American identity that could live up to the the country's democratic ideals. In this sense, the cultural memory of the entire nation reshaped into a form of social memory deeply infused with the traumatic outcome stemming from the brutal conditions that African Americans historically put up with. According to Jan Assman (1995) "(t)he concept of cultural memory comprises the body of reusable texts, images, and rituals specific to each society in each epoch, whose 'cultivation' serves to establish and convey the society's self-image" 
(132).

Hence, cultural memory and trauma go hand in hand when trying to underscore the idiosyncrasy of black Americans and the multifarious responses that their plight for an equal treatment has eventually posed in the national political agenda.

The momentous election of Barack Obama, the first African American as President of the United States, in 2008 may deceptively convey the idea that the country had left its racist DNA behind and had consequently washed away four hundred years of racial inequality. Sadly enough, as it has been recently shown through Ferguson's riots, the post-racist era is but a confection and a reality that is yet to come.

Bernice McFadden's tenth novel, Gathering of Waters, published in 2013, provides an example of the revision of the traumatic past for African Americans that stands as a valuable outlet to understand the blemishes of the socially tumultuous present. Through an act of imagination, a literary move that brings Toni Morrison's Beloved to mind, the novel recreates the last days of Emmett Till before he got brutally murdered for allegedly flirting with a white woman, despite the lack of facts or proves to demonstrate so. Imagination equates the enactment of fabulation that all the more configures the return of the repressed. This figuration bears the weight of the return of memory just to open the way for its transcendence and its understanding.

\section{African Americans' Social Death: Traumatic Memory and Destructive Stereotypes}

Gathering of Waters reveals the poetics of suffering just to pinpoint and make use of the history, cultural memory and traumatic past that model the lives of African Americans. Told by the city of Money, impersonated into a special narrator that oversees every move and mirroring Foucault's Panopticon (1971) induces readers in a "state of conscious and permanent visibility that assures the automatic functioning of power" (201) in a context of repressive state power with regards to racial issues, the novel brings forth an awareness of the interconnections between cultural memory and identity especially when these apply to understandings of national identity, something that has a long history in U.S. literary expression. Indeed, memory, and remembering, shape up the narrative of the novel which endeavours the ceaseless returns to the past that consequently shed light to the present.

Accordingly, trauma and sorrow have evolved into challenging concepts which overlap taking into account the transnational and transcultural memory of a considerable part of the African American population and emerge as perfect tenets to analyze the reconfiguration of the coeval black self as Paul Gilroy attempted to do in his groundbreaking study The Black Atlantic.

In McFadden's novel Tass Hilson and Emmett Till embody the traumatic self per excellence as their ultimate destruction, physically and mentally, is brought about by the aftermaths that result from the extremely violent experiences that black Americans have for so long been subjected to. In their story the concept of trauma is understood as "a wound inflicted not upon the body but upon the mind" (Caruth 1996: 3).

Duly, I submit that the racist stereotypes of the lustful Jezebel and the myth of the 'buck' as a violent, brutal and virile black man have a direct impact on the tragic destiny that falls upon Tass Hilson and Emmett Till respectively. Unable to fit in the social constrictions of the Cult of True Womanhood, black women were despised as lustful, hiper sexual and rather predators of white masculinity. This stereotype, determined after the biblical Jezebel, not only allowed white masters and overseers to openly rape African American women but also enabled white women to signal black women as sinners and therefore to exclude them from any human category, something that could eventually make them go insane. On the other hand, black men were commonly accused of being a social danger simply because they were rendered incapable of controlling their sexual impulses. The stereotype of the 'buck', or the hiper-sexual and sometimes animal-like black men, stood even more so as the perfect excuse to control African American men by punishing them with the most atrocious and cruel practice: the lynching. These two stereotypes are developed in Gathering of Waters and, more importantly, are believed and so get ingrained in the psyche, and fate, of both Tass Hilton and Emmett Till. The result is social chaos and racial havoc, something that is still to be worked out in contemporary U.S.

When Emmett Till arrives in Mississippi from Chicago to visit some relatives he instantly becomes the subject of something weary. His family is warned that the young Till "don't know the ways of the South" (McFadden 2012: 175). The myth of the buck triggers the fatal doom for Emmett when he is finally accused of having whistled to a white woman and her husband Roy Bryant and his brother-in-law J.W. Milam fetch him to eventually torture him to death aiming to teach him a lesson from the South. They ask him to get naked and the first thing they do is get down to ridicule Emmett Till's genitals. Bringing to the fore the myth of the buck as a massive sexual predator with a big penis, both Bryant and Milam mock about Till's penis to bring down black masculinity and to assert their own sense of white masculinity: "Roy, you see this? They say niggers got big dicks. Well, his ain't but the size of my picky finger" (McFadden 2012: 178). The myth of the buck has then a twofold meaning: both to stigmatize black men and, through the debunking of the African American masculinity, enables the white men to propose their masculinity over Emmett Till's. In fact, in an infamous attempt to prove their role as real men both attackers blurt out "You faggot" (McFadden 2012: 179) to young Emmett when he is at a loss and totally frightened by the violence encroached on him. After his death, Till's family is informed that the body 
has been brutally destroyed and the assassins even "( $t$ )ook his parts too" (McFadden 2012: 185). This terrible act, in which the myth of the buck reverberates, opens up a traumatic wound in the black community of Mississippi and especially in Tass who cannot believe that her new-found love has been murdered out of the blue.

She refuses to accept that death is the ultimate state of being and clings to her love for Emmett as the only way out: "Death is final? Wrong! Death is the end and the beginning" (McFadden 2012: 188). Cathy Caruth (1996) explains how in a traumatic experience that is filled with violence there is a moment of return in which the memory gets haunted not only by the violence of the event "but also the reality of the way that its violence has not yet been fully known" (6). The haunting and the returning attest to show how the cultural memory of African Americans is entirely pregnant with trauma and sorrow. McFadden's characters, then, dwell on what Alison Landsberg (1995) coined as prosthetic memory aiming to refer to memories that do not arise from an individual's lived experience but through some form of cultural or intergenerational inheritance and transmission. Far from being torn asunder, both Tass and Emmett trot out the prosthetic memory of U.S. racist policies.

Besides, the myth of the buck, which remains as an invention made up by the white world to control and impose violence upon black men, is unreal within the black community because Emmett Till dies without proof that he has done anything with the white woman nor with Tass Hilton herself.

Moreover, the subjectivity of black masculinity is not only shattered by imposing and debunking the myth of the buck but also by showing the obnoxious legal system that brought off African Americans at the margins of the law. As such, Roe and J.W. laughed when they admit that: "(e)ven if we did kill the boy...ain't no court in the land gonna convict two white men for killing a nigger" (McFadden 2012: 189).

It is rather mystifying to think about the contemporary U.S. legal system in the South when taking into account the preeminence over specific cases of violence against black men, be it the riots of Ferguson, the worldwide protests over the death of Eric Garner in police custody, or Trayvon Martin. A shocking moment, that arose a national conscience, arrived with the killing of Michael Brown, shot dead August 9, 2014, in Ferguson, after an encounter with the police while walking down the middle of a street. A grand jury decided to apply no charges whatsoever against Officer Darren Wilson, who said he acted in self-defense.

Once Emmett Till is dead, Tass Hilton's epistemology gets inextricably linked to his beloved lover by forging a bondage that goes beyond life. Her exclusion from society makes her enter what Franz Fanon (1967) stated as "zone of nonbeing" that aptly serves her to find release because it is only in this nonbeing zone "where an authentic upheaval can be born" (Fanon 1967: 8). Hilton's traumatic self will be lived in the assurance of such nonbeing zone wrapped up by the cultural memory that suffuses the rest of her life. This is so because, as Dominick LaCapra (1994) states, "(i)ndividuation is in certain respects pronounced in the modern West, but... what happens to the individual may not be purely indivudual, fot it may be bound up with larger social, political, and cultural processes that often go unperceived" (173).

Therefore, although she tries to get to grips with her life and gets married, her subjectivity remains attached to the inconsolable grief that resulted from Emmett Till's assassination. In this light, "(f)or many years, Tass's life was like an echo" (McFadden 2012: 204). Nonetheless, Tass's subjectivity is derailed also for the fact that her mother, who reflected the myth of the Jezebel in the eyes of the white South, never stood a chance to reveal the name of Tass's father. So, whenever Tass asked her mother about her father's identity she sharply replied: "I'm your mother and your father" (GW 2017). The feeling of eerie removal that appears at the thought of the paternal figure enhances the myth of the lust black woman that Hemmingway, Tass's mother, comes to signify throughout the story. As readers, we get to understand that this lascivious nature has been inherited by Hemmingway's mother, Doll, who even had sex with her daughter's lover. Lust and love get intertwined in Tass Hilton's matrilineal family in which water, as a traumatic outlet that brings forward the feeling of loss (Emmett's body was found floating in a river), has an important role, as the title of novel asserts. In a scene that reminisces on Zora Neale Hurston's masterpiece Their Eyes Were Watching God, both Hemmingway and Doll get surprised by a sudden flood that takes their passion, and eventually Doll's life, away.

Accordingly, as Janie Crawford in Their Eyes Were Watching God, Tass tries to overcome the stereotype of the lustful black woman by clinging to the happy moments that gained her a sense of reaffirmation and, at the same time, recalling Sethe in Toni Morrison's Beloved, Tass relies heavily on the process of rememory, to borrow from Morrison herself, to come to terms with her rendition of love. Unfortunately, and mirroring the social reality of many black Americans in contemporary U.S., Tass fails to get through the pain and winds up going berserk and out of control.

Tass's meandering into madness, due to her impossibility to grapple with her sexually traumatic family past as well as with the callous assassination of Emmett Till, is nothing but the result of the poisonous embracing of the uncouth racist stereotypes that white America created to justify the violence infringed upon African American men and women.

In this sense, Emmett Till and Tass Hilton, along with a vast number of African Americans abused by the racist politics of the U.S., represent what Giorgio Agamben (2000) has coined as the "dialectical oscillation between two opposites poles" (30) when talking about national identities. Both Till and Hilton fall into the category of "the people as a subset and as a fragmentary multiplicity of needy and excluded bodies" (Agamben 2000: 30) as they epitomize the subaltern citizen personifying African Americans that following the role that the racist stereotypes had given them 
were left to portray "an exclusive concept known to afford no hope" and therefore are highlighted as the personification of "the banishment of the wretched, the oppressed, and the vanquished" (Agamben 2000: 30).

The traumatic outcome that objectifies the black self is only overcome in the novel through imagination and fantasy. Tass Hilton can only get away with her pain by (re)imagining Emmett Till's social death and thus she brings him back to life with her imagination. It is only through this act of envisioning, which balances between madness and love, that Hilton can find solace and achieve a full subjectivity far from the indelible impression that the lustful memory of her mother and grandmother had caused on her. She leans on her love, despite the actual disappearance of the loved one, to surpass her trauma and to recompose the cultural memory that sets out the contemporary history of African America. So, when she becomes a widow she returns to Mississippi aiming to get reunited with Emmett Till (when truthfully she gets back to living in solitude while imagining that she shares her house with Emmett). In Tass's latest days, Emmett Till is omnipresent and a vividly figure that accompanies her everywhere: "(s)he walked back into the dining room and reached for her purse, which was dangling on the back of a chair. Before turning to leave, she looked right at Emmett and offered a soft, knowing smile" (McFadden 2012: 213). Hilton relocates her trauma by reconstructing and rethinking reality because, as Cathy Caruth (1996) proposes, "(t)hrough the notion of trauma...we can understand that a rethinking of reference is not aimed at eliminating history but at resituating it in our understanding, that is, at precisely permitting history to arise where immediate understanding may not" (11). Tass Hilton tries to convince herself that she would rather live in an imaginary state of mind in which she takes the lead on the physical world with the restrictive purpose of numbing her pain. Her resurrection of Emmett Till is but a response to both breach racist stereotypes and to regain self-control: "when a soul begins to slip from the binds of the physical world, the consciousness reverts to its natural state and once again it becomes open and receptive to the spirits that live amongst the host body" (GW 219). When she is finally able to share her last years of her life with her love, she confesses that "the only person who is the boss of me is me" (McFadden 2012: 227). The bridge has been accomplished and Tass and Emmett, being reunited through imagination, break away the social binaries of life and death, real and unreal, to foster new versions of rememory that can help out African Americans to rethink and reinterpret the blatantly cruel reality they have been condemned to live.

At the end of the novel, Tass is totally deranged and besotted by her after-life love for Emmett's memory. Every night she wraps in slumber striving to disclose her painful past by "searching for the night boy with the water voice" (McFadden 2012: 249). Within the closing lines we are told that a hurricane, which " $(\mathrm{t})$ hey named her Katrina" (McFadden 2012: 252), is approaching the coast. However, this destruction that is about to take on the southern coast is far away from Tass and Emmett who "skipped off into forever" (McFadden 2012: 252) just leaving behind a country in which racial reconciliation seems unattainable. Death is the ultimate moment in which justice is accomplished and (true) love fulfilled. In this way, Hilton's ending seems to echo Foucault's myth of the soul, "to survive when I die" (Foucault 2006: 230), as the pertinent utopia of effacement of suffering. The narrator of the story tries to gesture towards a robust form of healing by exhorting readers to "keep in mind that an evil act can ruin generations" (McFadden 2012: 252). The evil act is racism, violence, and the nefarious outcome of the racist stereotypes, the upcoming hurricane Katrina is still seen as "the whore" (McFadden 2012: 252) by black women, that destroy the subjectivity of African Americans. Gathering of Waters takes a conscious stand to refigure the endless trickling of the hitherto uninhabited memory into the state-sanctioned versions of it. In so doing, the novel totters beautifully and tragically on the precipice of the traumatic past to explain the racial nightmares of contemporary North America and nurtures readers to digest the broken soul of black Americans. The novel's last words, "(c)hoose wisely, dearest..." (McFadden 2012: 252), act as a direct message to readers, and to the whole country, to secure "the political survival of mankind" (2000: 30), in Giorgio Agamben's terms. It is only through a reconsideration of democracy, humanitarianism, and constituent power that this end can be achieved.

\section{Conclusions}

In the midst of a social turmoil that is shaking, yet again, the lives of African Americans in southern US, Gathering of Waters offers a new insight into the psyche of these black Americans that suffered the tremendous consequences of a violent racism that has riveted their existence for more than four centuries. It is no inconsequential to read McFadden's novel without bearing in mind the amounting violent episodes that are being spread these days in the US. The last one, whilst finishing this article, has its disgraced protagonist in Samuel Du Bose, a 43-year-old unarmed black man who was shot in the head and killed by a police officer, Ray Tensing, during a traffic stop. This never ending racial violence resonates in Gathering of Waters and through a historic and iconic figure for (African) Americans as Emmett Till, Mc Fadden reminds us about the power of healing as a national outlet through which reconstruct a more inclusive democracy. The final advice, "choose widely", intends to imagine, just as the whole novel deals with imagining, a better country only made up by all its citizens. This "gathering" of forces towards the completion of equality and to the debunk of racism is McFadden's ultimate goal at the writing of the novel. Memory and history merge to bring to the fore the pitfalls of a beloved nation that has many aspects to change. Emmett Till and Tass Hilton's deaths aim to open a meditation on the 
irrevocableness of the past to engender a scene of forgiveness and reconciliation and thus envisions a "horizon of transformation" (499), in Chung-Suing Lang's words (2003). Gathering of Waters urges a nuanced reexamination of choices before, during and after these turbulent times. However, the positive ending of the novel stands as a silver lining and thus envisions a new generation that will hopefully accomplish such feat. Let it be so.

\section{REFERENCES}

[1] Agamaben, G. (2000). Means Without End: Notes on Politics. Trans. Vincenzo Binetti and Cesare Casarino. Minneapolis, London: University of Minnesota Press.

[2] Assman, J. (1995). "Collective Memory and Cultural Identity". Trans. John Czaplicka. New German Critique 65. 125-133.

[3] Caruth, C. (1996). Unclaimed Experience: Trauma, Narrative and History, The Johns Hopkins University Press.

[4] Fanon, F. (1967). Black Skin, White Masks. 1952. New York: Grove.
[5] Foucault, M. (1977). Discipline and Punish: The Birth of the Prison. New York: Knopf Doubleday.

[6] (2006). "Utopian Body". Sensorum: Embodied Experience, Technology, and Contemporary Art. Ed. Caroline A. Jones. Cambridge, MA: MIT P. 229.234.

[7] Gilroy, P. (1993). The Black Atlantic: Modernity and Double Consciousness. London \& New York: Verso.

[8] Hurston, Z.N. (1990). Their Eyes Were Watching God (1937). New York: Harper and Row, Publishers.

[9] Hussen, A. (2000). "Presents Pasts: Media, Politics, Amnesia". Public Culture 12.1: 21-38.

[10] LaCapra, D. (1994). Representing the Holocaust: History, Theory, Trauma. New York: Cornell University Press.

[11] Lai, CH-S. (2003). "Re-Writing the Subject: The Throwness of Being in Multicultural Condition". Canadian Review of Comparative Literature 30.3-4. 495-503.

[12] Landsberg, A. (1995). "Prosthetic Memory: Total Recall and Blade Runner". Cyberspace/Cyberbodies/Cyberpunk: Cultures of Technological Embodiment. London: Sage.

[13] McFadden, B.L. (2012). Gathering of Waters. New York: Akashic Books.

[14] Morrison, T. (1987). Beloved. New Tork: Alfred A. Knopf. 